\title{
THE KNOWLEDGE OF THE SECURITATE: SECRET AGENTS AS ANTHROPOLOGISTS
}

\author{
FLORIN POENARU1
}

\begin{abstract}
In this paper I regard the Securitate (the Romanian secret police) as an epistemic form through which the socialist state gathered knowledge about reality, while it also performatively sought to create reality in keeping with its ideological presuppositions. More generally I suggest that the Securitate was in fact a form of (social) science deployed by the state in relation to its subjects. Just as any instrument of knowledge, the work of the Securitate was not simply descriptive but also, in the process, it aimed to shape its very object of inquiry. The Securitate was one of the institutions, central no doubt, through which the Romanian socialist state sought to define and protect its own, new, version of reality and social order. From this perspective, far from being an outcome of the socialist power, the secret police was what constituted that power to define and bring into being a new reality. In this process the secret agents played the role of anthropologists of the new world.
\end{abstract}

Keywords: secret police, socialism, knowledge, developmentalism, class

\section{Secret agents as anthropologists ${ }^{2}$}

The opening of the secret police files (the Securitate in Romania) has been one of the most socially and ideologically entrenched battles of postcommunism. The East German model of full disclosure and independent examination of the STASI files (despite its particular context undergirded by the complete take-over by the German Federal state) offered the blueprint for other post-socialist countries. Even more divisive was the role, function, and meaning of the data found in these archives. For some, the files would reveal the scope and brutality of the secret police activities and the identity of those particular individuals who wilfully (or less so) contributed to the bleak effectiveness of this ill-fated institution. Others, less seduced by the 'truth'effect of these archives, pointed out to the danger of simply prolonging the

\footnotetext{
1 Central European University, e-mail: florinpoenaru@gmail.com.

2 Many thanks to Norbert Petrovici and Florin Faje for their thoughtful comments and suggestions.
} 
logic of the secret police into the present, by continuing similar practices of de-masking, lustration, and ostracism.

Moreover, these debates magnified at the societal level a discussion that was otherwise limited to professional researchers: how to deal with and integrate archival data into historical narratives? Of course, the special nature of the secret police archive and its content added another layer of complexity. Two main approaches emerged. On the one hand, the files in the archive were endowed with the power to directly speak the truth about the regime and about the past. By opening them, it was expected that the post-socialist society would be able to understand whodunit and thus establish unequivocally the guilt. This was a moralistic perspective expressed in the language of Christian theology imbued with references to 'guilt', 'redemption', 'confession', 'sin', 'moral rectitude', 'forgiveness' in relation to both the 'victims' and the 'perpetrators'. Usually this was the perspective of the anti-socialist intellectuals, former dissidents and political prisoners of the regime. For them opening up the archive of the Securitate was a moral act linked to transitional justice. Such a perspective trampled the epistemological and methodological concerns of this data in favour of their immediate content and power of revelation.

On the other hand, professional historians and researchers ultimately expressed epistemological and methodological concerns and questioned the nature of these documents and their value as immediate generators of knowledge and truth. In addition, some streams of criticism also questioned the overlap between the state (as owner and administrator of these archives) and the statesponsored research of these archives. CNSAS (Consiliul National pentru Studierea Arhivelor Securității, the National Council for the Study of the Securitate Archives the state institution mandated to administer the archive) is the best example because its functionaries (state employees as it were) are at the very same time both administrators and researchers of these archives. This perspective placed the files of the Secret Police in a challenging theoretical and methodological conundrum, thus opening a pathway to a more solid, nuanced, and complex investigation with the specific tools of the historical social sciences.

However, in this perspective too, the secret police files remained strategic research sites about the socialist past. The archive constituted a source of knowledge about communism, albeit a more complex and challenging one than the moralistic approaches were able to or interested to concede.

In this paper I suggest a different view. I propose to analyse the archive of the secret police, its content and the manner in which the data was collected and archived as a particular form of knowledge. By asking what kind of knowledge the knowledge generated by the Securitate is, the focus shifts from the information contained in this archive to the mechanisms of its functioning and knowledgegenerating practices. It is thus also a way of moving from methodological concerns 
with data to an analysis of the formation of epistemic forms during socialism. As such, my interest is not in what the knowledge produced by the Securitate has to offer in relation to the present or to the socialist past. Rather, I am interested to understand the very mechanisms of production of this knowledge and its social and political relevance as it was produced. In this way - as a form of knowledge - the discussion about Securitate opens up two interrelated fields of inquiry that have remained so far under-researched (if not completely ignored) because of the collective bias in relation to the data collected in this archive.

First, there is the issue of knowledge-production during socialism. How and in what ways, through which means and institutions, did the socialist regime generate knowledge about the society it simultaneously sought to transform and govern? What was the relationship between state institutions and the party, between policy and ideology in this process? Secondly, and strictly related, what was the status and purpose of socialist social sciences in this process of generating and disseminating knowledge about socialism?

The question of knowledge and science and the relationship between them cuts through the heart of the socialist regime. Socialism was a political form that justified its political monopoly on a superior form of knowledge, on a scientific understanding (and mastering) of the historical transformation. This superior knowledge dictated the blueprints for the societal change at all levels envisaged by the socialist developmentalism. But two contradictions soon emerged. The first was related to the ways in which the socialist regimes were able to know (that is, to measure and compare) whether the transformations they had envisaged were indeed implemented. Put differently, what were the ways in which the socialist regimes were able to know whether the society was really being transformed according to their superior scientific plan? Moreover, if things failed to go according to plan, was this a shortcoming of the plan or of its lack of proper implementation? What were the means to know and measure these aspects in order to generate ideological and policy changes? Secondly, the socialist regimes were not forced to operate only in relation to an internal reality that they simultaneously sought to radically transform and manage. They had to interconnect with the capitalist world either directly through technology and capital imports or indirectly in the global market and in the geopolitical competition. How were the socialist regimes generating knowledge about these realities and with what tools, methods, and specialists? What was the impact of this knowledge on the socialist ideology and social science?

Such questions have been long overlooked in the research about socialism, obscured by other concerns that emerged from the transitology paradigm and from its critics. Recently, however, the trend is changing and concerns with the paradoxes of knowledge production during socialism come to the forefront for the Romanian case (see Cistelecan and State, 2015). 
In this paper I want to make a contribution in this direction through this proposal: the Securitate not only represented a particular form of knowledge during socialism but it was also a form of science deployed by the socialist state in order to make sense of and investigate the everyday reality of socialism. As such its modus operandi was very close to that of professional anthropologists working in the field and generating everyday knowledge. That secret police officers misrecognized western anthropologists as spies (as one of their own, that is) further testifies to this relationship (Verdery, 2014). Recognizing Securitate as a form of anthropological knowledge raises the question of its relationship with the social sciences of socialism and also casts into a new light the type of material that is usually referred to as the archive of the Securitate. This paper has only a preliminary role in this discussion - that of setting the stage for further inquiry.

\section{Theoretical and Methodological State Apparatuses}

What does it mean to analyse the archive as a form of knowledge and not simply as a source of knowledge? Ann Stoler suggests that a good starting point is to read along the archival grain (Stoler, 2009). As such, the archives have to be understood from the perspective of the state and its bureaucratic creators in contrast to the typical academic reading of such archives, either of the colonial administrations, or, recently, of the secret police that tries to subvert them by employing a perspective of the natives or of the victims, respectively. Stoler is then right to point out that while a reading against the grain might have powerful counterhegemonic effects, it also runs the risk of seeing the state as homogeneous, bounded, ordered, and with a clear purpose at the expense of administrative tentativeness, flux, internal splits, contradictions, and even chaos.

This observation is relevant for the Securitate archive as well. Anticommunism has portrayed this institution as all-powerful and omniscient, the real backbone of the regime's repressive and totalitarian nature. In so doing, it simply prolongs the image the Securitate was constructing about itself in order to augment its hallow of power. Moreover, such a view precludes a meaningful understanding of the actual functioning of the institution, especially of its historicity and actual embedding in the wider structure of the socialist regime and ideology.

By contrast, I take a different view and regard it as an epistemic form through which the state was gathering knowledge about reality, while it also performatively sought to create reality in keeping with its ideological presuppositions. The Securitate was not only a tool of control, suppression, and 
violence, but also a productive institution. It generated knowledge accumulated in the files we read today, but also in other various institutional practices and dynamics, legal provisions, and emotional and bodily dispositions, which generally tend to remain opaque due to the textualist focus on files and their factual content.

More generally I suggest that the Securitate was in fact a form of (social) science deployed by the state in relation to its subjects. Just as any instrument of knowledge, the work of the Securitate was not simply descriptive but also, in the process, it aimed to shape its very object of inquiry. The Securitate was one of the institutions, central no doubt, through which the Romanian socialist state sought to define and protect its own, new, version of reality and social order. From this perspective, far from being an outcome of the socialist power, the secret police was what constituted that power to define and bring into being a new reality.

The Bolshevik secret police, the CEKA, was established immediately after the Bolsheviks seized power in 1917, with the defensive goal of protecting the revolution from its many internal and external enemies. But its roots run deeper. In The Russian Revolution, Sheila Fitzpatrick (2008) wrote that the tsarist regime put in place a secret police after the assassination of Tsar Alexander II in 1881, a fact also stressed by Richard Pipes (1995). Many Bolshevik revolutionaries had direct contact with this secret police during their underground and exile years. They were constantly harassed by it, intimidated and learned how to trick it through the romantic mechanisms of disguise and faux names, still possible in a world far away from sophisticated data bases and profiling techniques. The strict internal discipline of the underground Bolshevik party was also premised upon the need to keep agents of the tsarist secret police away from infiltrating its ranks, something that was not always successful. Following this interaction, the Bolsheviks developed a certain habitus that would guide their actions after taking power, especially in the first years of War communism and during the Civil War. Exposing internal enemies would remain a constant task for all subsequent socialist regimes.

While the establishment of the tsarist secret police responded to very concrete needs of the state in order to deal with increasing anti-systemic and revolutionary movements from the late 1870s onwards, it was hardly a Russian phenomenon. Following the 1815 Vienna congress that reorganized Europe after the Napoleonic wars, the secret police was a bourgeoning institution across Europe, with a view to deter other European nations to upset the balance of power on the continent. States wanted to know beforehand about other states' planned actions in order to counter them. So began a golden age of European espionage, using mainly infiltrated agents, travellers, and diplomatic personnel (Crowdy, 2006). 
The secret police was an integral part of the larger modern principles of surveillance and policing developing from mid $18^{\text {th }}$ centuries onwards. Jeremy Bentham's ideas, famously analysed by Michel Foucault, signalled a wider change in the principles and forms of governance, suited to deal with the emerging industrial mode of production and its attendant specific social relations. These techniques of management, control and surveillance travelled back and fourth globally through imperial and colonial networks, tested and perfected in different milieus. In a different but connected vein, E.P. Thompson also showed the role secret police played in early industrial Britain in enabling the capitalist class to bring into being the British working class and pattern it according to its interests, by infiltrating the workers' circles and spying on their insurrectional plans (Thompson, 1963).

Abroad, the activity of the secret police was salient in building the European colonial empires and especially for projecting the British imperial power globally. This process entailed, among other things, the construction of a vast imperial archive. Thomas Richards (1993) noted that the myth of the imperial archive rests on two conceptions of knowledge: it has to be both positive and comprehensive. For the Victorians, the project of positive knowledge divided the world into small facts, understood as pieces of knowledge that were certain and that could, according to Mill and Comte, be verifiable. The accumulation of these tiny elements would lead then to a comprehensive knowledge, to the totality of knowledge. This imperial legacy of the 19th century inscribes the monopolistic possession of knowledge as undergirding the exercise of power. As Richards observed, in a distinctly anti-Derrida vein one might add, the archive is neither a building, nor a collection of texts, but an imaginary junction point of what is known or considered to be knowable - in short the phantasmatic representation of the epistemological possibility of total knowledge. The existence of the secret police is an outcome of the idea that everything about reality is and should be knowable, graspable, and archiveable.

But the archive is the interface between knowledge and the state. As Richards pointed out, in late 19th century and early 20th century the physical embodiment of this imperial archival fantasy was Tibet, the archive-state, the state as archive where Sherlock Holmes too retreats to enhance his wits:

The archival confinement of total knowledge under the purview of the state was Tibet, an imagined community that united archival institutions in one hieratic archive-state. In Western mythology Tibet was a sanitarium for the recuperation of an exhaustive knowledge that was always in danger of entropy, loss, or destruction. It was a fortress of solitude to which Sherlock Holmes, repository of a complete knowledge of all the streets of London, retires during his two-year disappearance, beyond the reach of call, to collect his wits by meditating on the sum total of knowledge itself. (Richards 1993:11-12) 
As such, the state is central to human life and knowledge. More to the point, state and knowledge are inseparable and the state becomes the very epistemological foundation for the existence of knowledge, which in turn must remain the purview of the state. Or, as Richards aptly put it, there is an inseparable link between classified information in the sense of ordered, catalogued, taxonomized, and classified information in the sense of hidden, cached, secret. Ordered and catalogued: the scientific knowledge is inextricably linked to the power of secrecy.

State knowledge and secret knowledge are almost interchangeable and the means to acquire them virtually indistinguishable. In the $19^{\text {th }}$ century, despite its ubiquity, spying was still an amateurish and non-formalized occupation. As Richards noted about India, it emerged from within the circles of intellectuals and friends belonging to universities and learned societies. The security police of the British Empire (the Secret Service, the Foreign Office) primarily recruited its agents and derived its methods of operation and surveillance from within these circles, particularly those involved in producing classified (in both meanings) and comprehensive knowledge, especially the geographical, demographic, and ethnographic societies. Such members were multi-tasked: spies producing knowledge about the colonial reality while their reports recommended forms of altering that reality, of making it more governable, transparent, and knowable.

The interwar period, and then the demands of World War II, enhanced and professionalized these practices of knowledge production and accumulation. Intellectuals and scientists were drafted into states' war machines in order to map out reality and contribute vital knowledge and expertise against the enemy. In the post-war era the new global hegemon - the US and its allies - continued the practice of producing knowledge about world via the influence of the secret police. David H. Price documented in detail, and with staggering examples, the collusion between the CIA and the anthropologists during the Cold War and the role the knowledge generated by the latter played for the activity of the former (Price, 2016). Just like previous imperial archives, the CIA sought to construct an archive that would be able to archive everything for further potential use. As Price writes:

As part of its effort to monitor and control international developments the early CIA collected and curated global knowledge. The agency envisioned that even the almost random collection of knowledge could eventually, if organized and retrievable, later be used in intelligence capacities. The scope of its approach to collecting disarticulated bits of knowledge is shown in Jane Schnell's classified article 'Snapshots at Random' (1961), which described a CIA collection known as the 'Graphic Register'. This was the agency archive of photographs collected from all over the world showing routine features and elements of 
physical culture. These photographs were catalogued and analysed for use at some unknown date in CIA operations... The CIA believed that if enough information was collected from enough angles, American intelligence could develop a comprehensive view of the world it sought to control. No mundane event or artefact was too insignificant for collection... This project was an emblematic representation of the CIA's mid-century project: it was well funded, global, brash, panoptical, without borders or limits. It was funded despite the unlikelihood that it would ever produce much useful intelligence, and working under conditions of secrecy removed normal general expectations of outcomes or accountability. (Price 2016:12)

In the context of the Soviet modernity in Eastern Europe, the agents of the secret police played a comparable role. They had to generate classified information about the socialist reality for the state, while also being asked to suggest modes of intervening in the reality that they were describing with a view to making it intelligible for state action and policies. As such, state knowledge and secret knowledge were virtually indistinguishable.

Just like in the western case, the institution of the socialist secret police, the Securitate in the Romanian case, was also constituted at the intersection between the state, the archive, and the practices of gathering, storing, and using knowledge. Ultimately, specific to the Securitate was its production of knowledge for the benefit of the state. Therefore, the kind of knowledge the Securitate produced, the theoretical and empirical tools used to generate and validate that knowledge and the social purposes it fulfilled offer important elements of investigation into the nature of this institution, beyond its typical and stereotypical description as a repressive one.

My argument is that what the Securitate did was to construct a form of anthropology for the benefit of the socialist state, not dissimilar to the colonial roots of the discipline as such. I have two reasons to suggest this point: one relates to form, the other to substance.

First, at the level of form, if we look carefully, the jargon of the Securitate apparatus, and its modus operandi, are remarkably similar to the anthropological toolkit that defined it as a legitimate discipline in the modern scientific division of labour. For example, both the secret agents and the anthropologists start out with a 'research plan' that guides their inquiry, which must remain flexible enough in order to be adjustable to the circumstances in the field. Both operate with categories of 'subjects', 'informants', 'hosts', 'goals', and 'networks'. Both activities presuppose a laborious work of gathering and managing fieldwork materials, such as field notes, written texts, diaries, declarations, and interviews and both have to use triangulation in order to verify and certify their findings. Thus, both are activities eminently based on writing, during various stages of their research. 
In both cases the writing-up process is a distinct activity, usually pursued in settings remote from the field and from the informants, incorporating previous notes, interpretations, and a specific jargon and rhetoric, while being aware of the institutional expectations and rules. Both have to report to their 'supervisors' in order to discuss the progress of the research and the possible paths of interpretation and action; both are also requested to undergo a personal process of self-reflection, trying to understand their position in the field and to achieve clarity about the sense of their own work (and to eliminate any possible sources of contradiction or conflict). ${ }^{3}$ Therefore, the Securitate archive constitutes a vast corpus of writings, highly political, ideological, and hegemonic, that isolates social facts about reality, which are then presented as expert knowledge by virtue of their epistemic authority. Or to put it differently, the Securitate is a mechanism that turns reality into words and as such makes scientific and epistemic claims.

Secondly, at a more substantial level, what anthropology and the Securitate share at the level of producing knowledge is their focus on social relations, social interactions, and social networks (see also Verdery, 2014). Basically what they look at and try to grasp is how the social is being constituted and how it evolves in time at the intersection between and as a result of the interaction of individuals, groups, and institutions. Finally, I would even argue that what is salient for both is a quest for - in fact a fixation with - 'hidden knowledge': not in the sense that knowledge is being purposefully hidden by somebody, but in the sense of 'deep knowledge', not easily accessible and evident, below the immediate surface of what meets the eye. Both anthropology and the Securitate start from the immediate, the everyday and the familiar in order to discover what is behind all that, larger networkers, longer historical trajectories, bigger structures and connections.

The practice of using secret agents for generating knowledge about reality should be regarded therefore as a particular practice among many other modern ones of rendering the world knowable and graspable. The secret agents and the anthropologists, while performing particular tasks in differently patterned institutions, nonetheless share a common epistemological ground in the way knowledge is defined, accumulated and used, specific to western modernity. Both are involved in processes of 'translating' the surrounding world in specifically codified languages and both share the ambition of rendering visible the hidden.

\footnotetext{
${ }^{3}$ For a detailed discussion of anthropology as a science of writing and making notes and especially fieldnotes, see Roger Sanjek 1990. Despite its unbearable post-modern take, it is a good account of how anthropology is essentially based on the process of classifying information obtained from informants. For what the Romanian secret agents and informers did and how their work resembles that of agents in the field, see Carmen Chivu and Mihai Albu, 2007.
} 
Ultimately, both produce thoroughly de-naturalizing effects, elevating concrete, immediate phenomena to abstract understanding. They are two of the most important epistemic tools through which the very concept of a global modern world becomes conceivable. Ultimately, they are a form of science of the social.

Two immediate concerns may be brought up here: first, that the practice of anthropology, and therefore the knowledge it produces and its purposes, is diverse and it cannot be captured in an ideal-type description of the discipline, especially following the manifold internal differentiations and dialogues that took place at least after 1968 and following the postcolonial critique from within the discipline; second, that while the practice of anthropology might be historically problematic and initially linked to practices of colonialism, eurocentrism, and racial domination, it still cannot be compared - even at its worst - to the activities and ultimate purposes of a paranoid and clearly repressive institution. Both concerns have merits, and they perhaps require a subsequent wider description. For the purposes of this paper suffice it to note that despite its internal difference and divergent historical paths what is specific to anthropology - its trademark - is the concept and practice of ethnography at its core: that is, in short, offering a written account about an observed reality. ${ }^{4}$ This was what the Securitate was in principle called to do - with the significant difference that it benefited from the leverage of state institutional and legal backing to do its ethnography. But, as I will discuss below description is never simply a description but it has a performative character as well, at the same time creating the realities it purports to simply describe. Surely, performative effects are usually different and highly dependent upon the context of their appearance.

As for the second concern, I do not suggest here that anthropologists are anything like the socialist secret agents (even though David H. Price documented a number of cases when anthropologists have been exactly that, willingly or not), and not even like their colonial ancestors. Rather, I suggest that there is an isomorphism between their activities and that secret agents, for reasons I will discuss below, employed anthropological tools.

Katherine Verdery too observed the link between Securitate and anthropology in the study of her Securitate file as an ethnographic object. She noted, for example, how the Securitate agents thought she had received intelligence training by observing her own anthropological practice: keeping fieldnotes, using informants that received a code-name, jotting down general information about context and environment, operating with a special code and so on. No wonder,

\footnotetext{
${ }^{4}$ Of course, things are never that straightforward and even such a minimal definition is problematic. For a mapping out of the wider predicaments of ethnography as concept, practice, and genre, see the classic Clifford and Marcus, 1986.
} 
they believed, the anthropologist must be a spy if they shared so much of the actual process of gathering knowledge and transposing it into pieces of information that could be archived, retrieved, and reassembled together. This was not simply a parallel concerning methods, but a more structural one. As Verdery also noted, what the secret policemen ultimately tried to do was to 'make close examination of everyday behaviour and interpret what they found' (Verdery 2014:87). The Securitate, therefore, had as its object of inquiry the everyday life of the socialist regime and as such they had to deploy a series of tools, but also to generate a notion of the social itself and how it works, in order to grasp its dynamics and report about it to the higher echelons of the party. Indeed, they were the 'eyes and ears' of the party, but in this very anthropological sense: a specific form of knowledge and practice that sought to understand the nuts and bolts of a society in its daily, everyday life interactions.

In their influential work Laboratory Life, Bruno Latour and Steve Woolgar (1986) explored the daily routine of a group of scientists that led to the creation of scientific facts. What they noticed was that most of the work of the scientists consisted largely of producing various forms of inscriptions and that most of their time was spent writing and revising. This writing accumulated as papers to be published in scientific journals accompanied by an entire corpus of diagrams, texts, charts, maps, and so on. The authors concluded that the laboratory was a place that took statements of one level of facticity and transformed them into other levels, in a 5-step scale that ranged from very factual to speculation. Latour and Woolgar offered a processual definition of science. Instead of a substantive answer to 'what is science?' they suggested to look at practices and analyse what the scientists $d o$.

This idea of science is helpful for understanding the secret police as a form of 'mapping' the reality aimed to transform the everyday reality into scientific inscriptions, legible, intelligible, and usable for the exercise of power. The secret police is then a large social laboratory established by the state in which social facts are transformed into scientific facts through processes of recording (testimonies, conversations, meetings, and so on), observation, codification, taxonomy, cartography, reading and, above all, writing for the use of the political power. Ultimately, in modernity, science is nothing else but the promise of rendering intelligible and visible, through various mechanisms and techniques, things that are otherwise opaque, discreet, and invisible.

But in this case there is more to it. The Securitate was tasked not only to gather knowledge but also to actively take part in shaping the new socialist reality. As it were, the Securitate had to integrate in its functioning two types of opposing knowledge and knowledge production mechanisms. On the one hand, the positivist and empirical knowledge which emerged by engaging the reality 
through particular knowledge tools. On the other hand, a priori knowledge that emerged from the theory of communism, that is, from the truth of ideology. This a priori, superior knowledge had to inform the remaking of reality and had to, by definition, take precedence over the empirical reality as such.

To put it differently, the secret police was called simultaneously to acquire factual knowledge (through surveillance, recordings, etc.) while subordinating it to the truth of ideology (which entailed deciding who was a spy, a traitor, etc. based on theory and ideology). The real contradiction of knowledge at the heart of the socialist regimes, best exemplified by the secret police, is that they had to rely at the very same time on both deductive and inductive logic. Inductive logic meant broad generalizations based on very particular and fragmentary details: for example, the observation of a dialogue between two dissidents would necessary be the sign of an anti-regime complot sponsored from abroad. The possibility for these broad generalizations was offered by the very ideological presuppositions on which the regime was premised.

Already rooted in Marxism there was the strong imperative that the task of any socialist politico-philosophical practice was to change the world. This belief was quintessential for the Bolsheviks that took power in USSR in 1917 and in practice defined the existence of the Soviet system as a better alternative to Western modernity. All spheres of life were to be thoroughly transformed in keeping with the socialist thinking and against all bourgeois remnants. The material world, people, and social relations had to undergo, simultaneously, a radical break with the past. In this context, the arts also had to break with their focus on representation (of nature, of reality) and actively take part in the revolutionary transformation of society by changing ideas, habits, feelings, and so on.

This idea was well rooted in the avant-gardes of the early $20^{\text {th }}$ century and after 1917 became part of the socialist project more generally. But if the artists and cultural creators were called upon to take active part in this sweeping transformation, so were the secret police officers (Vatulescu 2005). They had to monitor and report on people, but also to actively take part in moulding them as New Men. At the heart of the socialist secret police was not only a desire to repress and control, but also to actively and performatively create better citizens. ${ }^{5}$ Or, as Rancière put it apropos of police in modernity

The police is not a social function but a symbolic constitution of the social. The essence of the police lies neither in repression nor even in control over the living. Its essence lies in a certain way of dividing up the sensible (Rancière 2010).

\footnotetext{
${ }^{5}$ It is perhaps useful to note in this context that the name of the foreign intelligence service of East Germany was: Hauptverwaltung Aufklarung -the Department of Enlightenment (Garton Ash, 1997:16).
} 
Deriving originally from the distinction J.L. Austin made between constative and performative utterances, performativity describes the active making of reality through speech and discourse. The performative act comprises the locutionary level (the speech itself, organized by phonetics, syntax, grammatical rules and so), the illocutionary level (the social function of the locution), and the perlocutionary level (that is the social effect it generates). Discourse has the reiterative power to produce the phenomena it regulates and governs. Performative acts cannot be judged according to criteria of true and false, as it is the case with the constative ones, but with some criteria measuring their effectiveness or persuasiveness. Precisely the capacity of power to performatively construct the reality and the subject of its exercise, also offers the space in which resistance to that power can be formulated by breaking the chain of reiterability.

Alexei Yurchak (2005) developed this point in a compelling fashion in relation to Soviet communism. He believed that what characterized this system was people's repeated enactment of the form of the regime's authoritative discourse, without attending to its constative meaning. The repeated performance of these fixed forms opened ways for the emergence of various meaningful and creative activities, communities, beliefs, and networks. As it were, the very exercise of power through its performative celebrations, parades and ritualistic speeches created the Soviet reality while also engendering the preconditions for its own subversion.

One of my informants witnessed the following episode one day in the CNSAS reading room. While consulting his own surveillance file, a man took out a pen and started to make his own annotations on the original, marking those things that were factually true and crossing out those that were false or incorrect - to the horror of the archive's guardians. ${ }^{6}$ This is perhaps the perfect metaphor, the extreme case, of how the files were generally read in postcommunism: with an eye to their correspondence to reality, to their trueness in relation to facticity. But, as suggested already, this kind of reading might miss the point.

The common thread of the files is that they seem to document various attempts at challenging the reality presented by the socialist regime, attempts at formulating, presenting, disclosing a different reality. To put it differently, secret files registered attempts at or actual instances of challenging the socialist Reality through an account of reality based on a representational and empirical perspective, ranging from banal conversations about the lack of bread in shops to

\footnotetext{
${ }^{6}$ This episode also raises interesting questions about ownership and property of the archive. Who do the files belong to? Do the people surveilled have any claim to the files? Are the files solely the property of the state even though the files usually contain personal items, like letters, intimate conversations and so on? I owe this point to Katherine Verdery.
} 
more political positions and to summaries of Radio Free Europe bulletins. These small acts of dissidence, or to put it in Yurchak's terms, these refusals to participate in the performative production of the socialist Reality that every citizen was expected to do were then codified in the language and imaginary of the Securitate which effectively meant the beginning of anti-regime complots, or the traces of an imperialist plot, or acts of provocation and unrest and so on.

\section{Class Struggle for Knowledge}

In Bourdieu's Secret Admirer in the Caucasus Georgi Derluguian (2004) noted that one of the causes that have laid the foundation for the collapse of the socialist states was informational scarcity: that is, the lack of genuine information on the actual state of the economy and society. The attempt to establish a monopoly in every sphere of life, from the economic plan to the sex life, deprived these Party-States of a mechanism through which to evaluate and control the performance of their own bureaucracies and work of the intelligentsia.

Similarly, but in a different vein, Andreas Glaeser (2010) proposed an epistemic explanation of the failure of state socialism. For Glaeser socialist states failed because the socialist elites did not manage to produce adequate understandings of everyday functioning of the society. Therefore, they could not develop timely reforms of the system, in keeping with wider societal mutations. By remaining strictly observant of ideological dogmas, the party leaders lost touch with the actual reality and also lacked the proper means to understand it. Ultimately, communism failed when it could not sustain any of its pretences: neither that of a superior knowledge producing a better life for all, nor that of the power to actively shape reality for the better.

While Glaeser is right to point out these inbuilt tensions within the socialist system, he overstates the case concerning the extent to which various socialist regimes were keen to implement what he calls a 'monolithic intentionality': that is, the subordination of the entire social reality to the ideological norms devised by the Party. Socialist parties did not produce only hard-core ideologues shaping the new socialist life discursively, but it also had to create various technical specialists and scientists able to run the economy and the society. While the regime tried to keep them in check and subordinated to the ideological project, they nonetheless had their own autonomy conferred by the mastery of technical and scientific competences and knowledge. What Glaser fails to see therefore, like many western scholars of socialism, is the class nature of the regime itself. Instead of seeking the contradictions of the socialist system in a too rigid attachment to ideology that prevented meaningful knowledge about the reality, as Glaeser 
suggests, we should note instead how the very structure of the socialist regimes created insurmountable contradictions, both social but also at the level of knowledge production and, as such, at what was possible for the socialist social sciences to achieve.

Silviu Brucan (1990) also referred to the constantly growing contradiction between the ideological foundations of the socialist regimes and their social realities. Because these regimes were as far as possible from the Marxist idea of communism and even from Lenin's concept of development, the actuality of actually existing socialism was hidden under more and more ideological verbiage. This created a particularly uneasy situation for the socialist social sciences especially that, in the apt formulation of Brucan, social data and facts acquired an 'illegal' character (Brucan 1990:39). It seems that the socialist regimes could not and did not want to look into their own functioning through the social sciences because they knew what they were going to find there: their own contradictions and internal tensions. The activity of the secret police was called to nonetheless generate this necessary knowledge for the use of the party-state, with scientific means, but only for the eyes of the officialdom. Only such an institution that was simultaneously loyal to the regime but distinct from the party-state hierarchy was suited to satisfy the paradoxical knowledge requirements of the regime: that of creating reliable though nonetheless cached knowledge about the socialist society.

Such a mechanism was even more necessary since it articulated with the class contradictions at the heart of all socialist societies. Every socialist party faced a similar conundrum after taking state power: on the one hand to quickly swell the numbers of industrial workers which represented the ideological justification of the socialist party's grip on power as revolutionary avant-garde; on the other to dismantle the old state and form a new one around loyal bureaucrats and cadres. On top of that, the Soviet model of socialism was predicated on the nationalization of the means of production and the institutionalization of the Plan as the main mechanism of rationalization of the economic and social life. This instantly created at least three social classes of actors with both converging and diverging interests: the emerging industrial workers, the party-state bureaucracies that merged together in the control of the state and production, and the technocracy in charge of devising and implementing the Plan that even though initially was recruited and had strong links with the top echelon of the partystate nexus it nonetheless enjoyed its own degree of autonomy by virtue of its technical competence. This was also the class mostly in need of accurate social scientific data about the socialist society in order to devise the Plan accordingly and correct its implementation. Not surprisingly at all therefore, in the Romanian case Miron Constantinescu, a high profile politician, was the first person in charge 
with devising and implementing the first 5-year Plan, but also the person who contributed the most to the development of a socialist scientific discipline at the very heart of the socialist state (Poenaru, 2015; Petrovici and Bosomitu, this issue).

This social arrangement once set in motion it had its own sui generis course as a result of the internal design of socialist developmentalism, but an important external factor also had an important pulling force, especially in the Romanian case. The pivoting towards the west after the second half of the 1960s increased the role of the technocracy, which was now called not only to manage the Plan but also to coordinate the cooperation with the global capitalist world. This naturally increased further the need for specialization of the technocracy and its dependency on a different type of knowledge than the one provided by the official ideology. Among other causes it led to an inevitable rift between the party-state bureaucracy and the technocracy in the very process of exercising state power and economic development.

It was in this context that the secret police came in handy in order to keep track of everyday knowledge, and more importantly, to monitor the activities of the technocracy, unbounded now by the adherence to the superior knowledge of socialism. Then, the population most targeted by the Securitate surveillances, especially in post-Stalinism, was the technocracy, simply because it was best situated in a position from which to challenge the Party's monopoly of knowledge and information and its evaluations on the state of the economy and society. The Securitate was a tool in the hands of the party-state bureaucracy that was used in order to monitor the actions of the technocracy, and as a deterrent to the accumulation of knowledge in alternative centres.

The role of the Securitate becomes even more important if we consider the landscape of scientific knowledge production. By and large, all academic fields essential to governance, such as the economics, politics, diplomacy, and so on were strictly subordinated to party control through a series of party-schools (Gheorghiu, 2007). So was philosophy, considered essential for developing party ideology and staunch cadres. Disciplines like sociology and anthropology that could offer a challenge to the Party's monopoly of power by confronting it with its actual societal effects were institutionally castrated and neutralized and thus rendered to a large degree irrelevant (see Poenaru, 2015). These niches did accommodate a series of interesting practitioners and sound sociological work (for example works in urbanization, but also the fertile intersection between sociology and literary studies that generated an important sociology of the intellectual field - see Gheorghiu 2007), but it was far from the critical potential manifested by the social sciences across the socialist block in challenging official 
knowledge production and dissemination. ${ }^{7}$ Even worse, history, archaeology, and literary studies - usually disciplines in which critical and alternative knowledge practices and interpretations get articulated - were incorporated into the practices of constructing the nationalistic cult of personality. In this context the Securitate had to fill the task of monitoring and reporting back on what was happening in the society to the benefit of the party. ${ }^{8}$

This division of labour for knowledge production and accumulation was discernable also in the different pathways of formation specific to various classes of the socialist state. Initially, the party cadres were formed in party schools that constituted accelerated forms of upward social mobility mainly by virtue of 'healthy origin' with a view to replace the interwar bourgeois ruling classes and bureaucracy. Skill and knowledge were less important than loyalty to the party and to the socialist ideology. But because of that, party schools also lacked symbolic authority since admission was not tied to knowledge but to the desire for advancing in a political career. As Vladimir Pasti showed, every manager of the socialist bureaucracy had to be first of all a 'good socialist' (Pasti 2006). This notion was then formalized based on a reasoning in which one's motivations and values depended more on one's social milieu and upbringing than on personality. This led to the creation of the 'dosar de cadre' (the cadres dossier) - a register in which the entire biographical trajectory of a person was recorded and measured against the criteria of ideological and party fidelity.

Starting in late 1960s, however, significant transformations of the socialist state and economy posed a challenge to this model. The Party started to reward technical competences, not just political loyalty. In this context, the university system gained a different symbolic status, together with a vast injection of funding. Entering university was now considered a major achievement, holding the promise of a firm sense of future and prestige. To put it differently, the socialist state began to cultivate its own professional middle class, with consumerist expectations and specific lifestyle.

Tensions soon abounded. While party apparatchiks were overall less prepared to run the economy, they nonetheless remained in charge of the commanding heights of the economy and of the Plan. They retained the power to allocate and distribute resources and generally to establish the overall directions of

\footnotetext{
${ }^{7}$ See in particular the works of János Kornai, Ivan Szelenyi, and Pavel Câmpeanu who wrote his books under pseudonym and in English, in contrast to his Hungarian counterparts.

${ }^{8}$ Remarkable in this sense is the collection of documents from the Securitate archive compiled by Florian Banu (2012). There it becomes evident how the Securitate was struggling against austerity measures affecting its own activity to document all aspects of the everyday life during the 1980s, from systemic aspects like the distribution of goods in shops to accidental cases like food poisoning in children's camps. The entire social world was putatively the object of the Securitate's observation activity.
} 
the society. Consequently, the technocracy remained both politically, economically, and symbolically subordinated to the party cadres, and ideologically subordinated to the working classes, which was also on average slightly better paid (Brucan, 1990). The technocracy, naturally, began to accumulate frustrations in relation both to the party and the working classes and to become severely hindered in its development by the political monopoly of the party.

These sentiments were amplified by the economic crisis beginning to take root at the end of the 1970s and to reach dramatic proportions during the 1980s. Then, the mobility within the socialist system came to a virtual halt, frustrating the technocracy which was wasting its skills while being excluded from power by incompetent bureaucrats. ${ }^{9}$ In addition, because of the deep suspicion of the Party towards the intelligentsia, the recruitment of cadres was done internally from party schools which, following the 1960s professionalization, were able to produce technical specialists too, with competences to run the economy. This was however at the expense of theoretical and ideological specialists which could have generated alternative political projects and economic visions within the top echelons of the Party. The professionalization of the party schools and their abandoning of ideology explain perhaps why there was no reformist Marxist current in Romania, compared to other countries of the former bloc, which could have been politically productive during the drab 1980s (Gheorghiu, 2007).

In this context, the Party, through the 'eyes and ears' of the Securitate, sought to keep under control and surveillance the disenchanted and frustrated intelligentsia, while it actively devised policies for limiting its growth. In the late 1970 s, the party reorganized the education system by drastically limiting the number of university places for socio-humanist disciplines, while encouraging only certain technical ones, such as engineering, traditionally more aligned to the party interests (Brucan, 1990). This was necessary since under the new economic constraints the party could not absorb anymore the graduates from these disciplines, leaving them largely disenchanted and prone to rebellion.

But the party was not interested in actively repressing the technocracy either. Rather, it aimed just to discourage outright rebellion through constant harassment, intimidation, and threats while keeping at bay the accumulation of alternative knowledge. One of the strategies envisaged by the Securitate and the party was to allow the technocracy limited cultural consumption and cultural practices and to encourage escapist, non-political activities. Of course, serious collusions did take place occasionally, some very violent, others leading to serious reprimands and even short-time jail sentences. But by and large, the idea of a particularly harsh oppressive regime was not warranted. The Securitate was perhaps more intrusive because of its instructions to know everything, but not

\footnotetext{
${ }^{9}$ A longer and more complex discussion in Konrad and Szeleny (1979).
} 
more violent. The myth of the violence of the Securiate is an a posteriori one, devised by the intelligentsia as a class in order to justify its lack of political courage against the party as well as the lack of any organized, sustained forms of dissidence.

Unsurprisingly then, in post-communism it was largely the intelligentsia that had a high stake in opening the Securitate files and in cultivating the anticommunist politics of history and memory. Ultimately, the files of the Securitate comprised the biography of the intelligentsia as a class in formation, which was germane for the process of claiming political and economic hegemony in postcommunism. Consequently, the post-communist pressures to open the Securitate archive are a distinctive mark of the class struggle already constitutive of the socialist society, now prolonged in post-communism, but displaced as concerns with 'memory', 'justice', and 'truth'.

By invoking the ubiquity of the Securitate surveillance, as an epitome of the brutality and dictatorship of the socialist regime in general, the files of the Securitate were elevated to the status of irrefutable proofs for the need to condemn the past in the name of the formal bourgeois rights pertaining to free expression and protection of the private sphere. The files became the traumatic legacy of the past and the evidence for the necessity to dismantle the old society and build a new one based on western values. As such, the files could always be mobilized as reminders whenever the hegemonic consensus of the transition was questioned: they became the insurmountable limit to understanding the past, the vantage point for its interpretation.

The temptation to inscribe the Securitate as the perpetrator of all evils, to turn the secret agents into societal scapegoats has a long tradition within the socialist regime itself. This model was offered by the de-Stalinization process inaugurated by Khrushchev's secret speech in which the secret police was blamed for siding with the dictator against the party and the working class. Similarly, in Romania, in a speech in august 1968, at the height of his attempts to consolidate power around the nation, Nicolae Ceaușescu also pointed the blame in the direction of the Securitate for the abuses of the 1950s and for generally working independently against and outside the party control (Banu, 2012).

This engendered not only a reorganization of the Securitate, bringing it under close party control, but also inaugurated a period of coming to terms with the Stalinist past and with the crimes of the Securitate. During the 1970s, literary, cinematic, and intellectual productions openly confronted the Securitate abuses, sometimes authored by people who actively suffered as political prisoners. The centrality of the Securitate as evil is not a post-socialist invention, but an ideological construction of the party itself from the time when it actively sought to create its own intelligentsia. The two are inextricably linked. 
But there is a deeper complexity concerning the relationship between the Securitate and the Party. Despite their close connection, their interaction was far from frictionless, thus cautioning against simplistic views that see the Securitate as entirely subordinated to party politics. In fact, the Securitate enjoyed a high degree of autonomy and some of its actions managed to frustrate party apparatchiks. In Romania, the shattering event was of course the defection of general Pacepa to the CIA in 1978.

In fact, what the view that simply subordinates the Securitate to the party and to the dictatorial logic of the regime itself misses is in fact the historical transformations that shaped the institution itself. It also hides the fact that we know so little about this organization and its workers, beyond the ideological simplifications of anti-communism. In the 1950s, the Securitate rank-and-file was mostly recruited from working class and peasant backgrounds. Some of its initial violence and hands-on behaviour were a result of the class struggle these people were called upon to enact against the former bourgeois owners and exploiters. The Romanian fascists -the legionars - were also prime targets for this institutionalized violence, and some of them were recruited in order to help catch and re-educate others (see Totok and Macovei, 2016). But just like in other areas, from the 1970s onwards, the Securitate started to recruit people based on training and merit, educated in a parallel system of institutions. For secret police officers too, their ideological commitment and class origin became less important than their skills.

In short, the Securitate itself was gradually becoming a corpus of technical cadres, almost like a mediator between party-state bureaucracy and technocracy - to be sure, a very privileged one in terms of its position within the society, but also in terms of power and access to knowledge. They were the first to notice the disastrous effects of party policies, especially in the 1980 s, and to actively attempt to resist party tasks. What was initially an attempt of the party to try to subordinate the production of knowledge about everyday life gained an autonomy of its own and became a counter-force to party interests and knowledge production mechanisms. This trajectory dovetails once more the multiple paradoxes at the heart of knowledge production during socialism that this paper tried to stake out.

\section{REFERENCES}

Banu, F. (2012). Amorsarea Revoluției. România anilor 80 văzută prin ochii Securității. Târgoviște: Cetatea de Scaun.

Brucan, S. (1990). Pluralism and Social Conflict: A Social Analysis of the Communist World. New York: Praeger. 
Chivu, C., Albu, M. (2007). Dosarele Securității: Studii De Caz. Iași: Polirom.

Clifford, J., Marcus, G.E. (eds.) (1986). Writing Culture. The Poetics and Politics of Ethnography. Berkeley. University of California Press.

Crowdy, T. (2006). The Enemy Within: A History of Espionage. Oxford: Osprey.

Derluguian, G.M. (2004). Bourdieu's Secret Admirer in the Caucasus: A World-System Biography. Chicago: University of Chicago Press.

Fitzpatrick, S. (2008). The Russian Revolution. New York: Oxford University Press.

Gheorghiu, M.D. (2007). Intelectualii în cîmpul puterii: Morfologii și traiectorii sociale. Iași: Polirom.

Glaeser, A. (2011). Political Epistemics: The Secret Police, the Opposition, and the End of East German Socialism. Chicago: The University of Chicago Press.

Garton Ash, T. (1998). The File: A Personal History. New York: Vintage Books.

Konrad, G., Szelenyi, I. (1979). Intellectuals on the road to class power. Harcourt Brace Jovanovich.

Latour, B., Woolgar, S. (1986). Laboratory Life: The Construction of Scientific Facts. Princeton, NJ: Princeton University Press.

Pasti, V. (2006). Noul Capitalism Românesc. Iași: Polirom.

Pipes, R. (1995). Russia under the Old Regime. New York: Penguin Books.

Poenaru, F. (2015). 'Miron Constantinescu'. In State, A., Cistelecan, A. Plante exotice. Teoria și practica marxistilor români. Cluj: Tact.

Price, D.H. (2016). Cold War Anthropology. The CIA, the Pentagon and the Growth of Dual Use Anthropology. Durham and London: Duke University Press.

Rancière, J. (2010). Dissensus on Politics and Aesthetics. London: Continuum.

Richards, T. (1993). The Imperial Archive: Knowledge and the Fantasy of Empire. London: Verso.

Sanjek, R. (1990). Fieldnotes: The Makings of Anthropology. Ithaca: Cornell University Press.

State, A., Cistelecan, A. (2015). Plante exotice. Teoria și practica marxistilor români. Cluj: Tact.

Stoler, A.L. (2009). Along the Archival Grain: Epistemic Anxieties and Colonial Common Sense. Princeton, NJ: Princeton University Press.

Thompson, E. P. (1963). The Making of the English Working Class. London: Penguin.

Totok, W., Macovei, E.I. (2016). Intre mit și bagatelizare. Despre reconsiderarea critică a trecutului, Ion Gavrilă Ogoranu și rezistența armată anticomunistă din România. Iași: Polirom.

Vatulescu, C. (2010). Police Aesthetics: Literature, Film, and the Secret Police in Soviet Times. Stanford, CA: Stanford University Press.

Verdery, K. (2014). Secrets and Truths: Ethnography in the Archive of Romania's Secret Police. Budapest: CEU Press.

Yurchak, A. (2005). Everything Was Forever, until It Was No More: The Last Soviet Generation. Princeton, NJ: Princeton University Press. 